\title{
ウサギ下顎骨の仮骨延長における待機期間が 初期の骨形成過程に及ぼす影響
}

\author{
相田高幸・吉岡泉・冨永和宏 \\ 福田仁一 \\ Effect of latency period before mandibular \\ distraction on early osteogenesis in rabbits
}

\author{
Takayuki Aida $\cdot$ Izumi Yoshioka $\cdot$ Kazuhiro TominAGA \\ Jinichi FukUdA
}

\begin{abstract}
Recently, distraction osteogenesis is widely used in the cranial and maxillofacial skeleton. However, the need for a latency period before mandibular distraction remains controversial, with recommendations ranging from 0 to 14 days. We used a rabbit model to determine the ideal latency period for mandibular osteodistraction. We performed a bilateral subperiosteal corticotomy of the mandible and applied an external distraction device. We used 0 -, 2 -, 5 -, and 10-day latency periods. Distraction was done at a rate of $0.5 \mathrm{~mm}$ per day $(0.25 \mathrm{~mm}$ per 12 hours $)$ for 10 days to elongate the mandible by $5 \mathrm{~mm}$ after each latency period. Hematoxylin-eosin stain was used for histological observation, and bone was labeled by several fluorescence substances, which can be observed with a fluorescence microscope.

In the 0 -day latency group, the lengthened region was filled with fibrous tissue. Cartilage-like islands were found along the lengthened region. In the 10-day latency group, the lengthened region was almost completely filled with woven bone. In the 2 -and 5 -day latency groups, there was a distraction gap, with mineralization zones at the periphery of this fibrous interzone. The primary osteon remodeling zone were located at both ends of the mineralization zones. In the 5 -day latency group, newly formed bone was observed around the periosteum. These results indicate that 5 days is the most suitable latency period for mandibular distraction in the rabbit.
\end{abstract}

Key words: distraction osteogenesis (仮骨延長法), latency period (待機期間), mandibular lengthening (下顎 骨延長), rabbit model (ウサギモデル)

緒 $\overline{\overline{\bar{一}}}$

生体の骨形成反応を利用した仮骨延長法は, 1950年代に Ilizarov ${ }^{1,2}$ ) の創外固定器を用いた延長法が開発されて以 来, 主に整形外科領域において長管骨に対して普及してき た. 本方法は, 1973年 Snyder ら ${ }^{3)}$ によってイヌの下顎骨 延長の実験的研究が報告され, 膜性骨である顔面骨にもそ の応用が考えられるようになった. 1992年には McCarthy

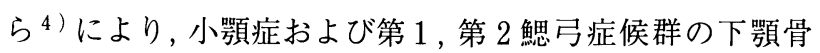

九州歯科大学口腔外科学第 1 講座

(主任 : 福田仁一教授)

First Department of Oral and Maxillofacial Surgery, Kyushu Dental College (Chief: Prof. Jinichi Fukuda) 受付日 : 平成 13 年 3 月 14 日
に対して，はじめての臨床応用が報告された。現在では, 種々の先天性疾患, 症候群, 発育異常, 腫瘍切除後の顎骨再 建 $^{5}$ ), 歯槽骨の垂直的延長 6 ) など, 幅広い症例に適用され ている.

このように口腔外科領域でも普及してきた仮骨延長法で あるが, 現在でもさまざまな問題点がある. その 1 つは従 来の顎矯正手術や骨移植術に比べて, 治療期間が長いこと である. 仮骨延長法の基本的スケジュールは骨切り, 待機 期間, 延長期間, 固定期間からなり, 延長装置を装着してい る期間は数か月に及び, この間の患者の苦痛は大きい.し たがって，それぞれの期間がどのような意義をもち，どれ くらいの期間が必要であるのか十分検討されるべきであ る.

整形外科領域の手術において, 長管骨の延長で待機期間 


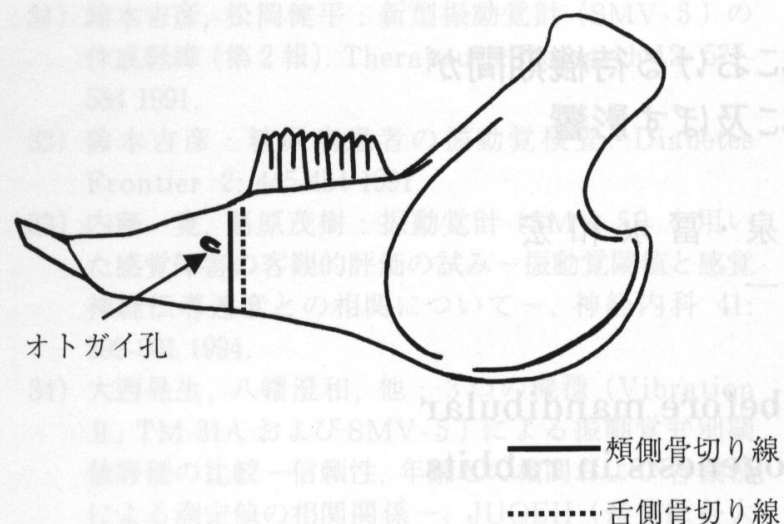

オトガイ神経

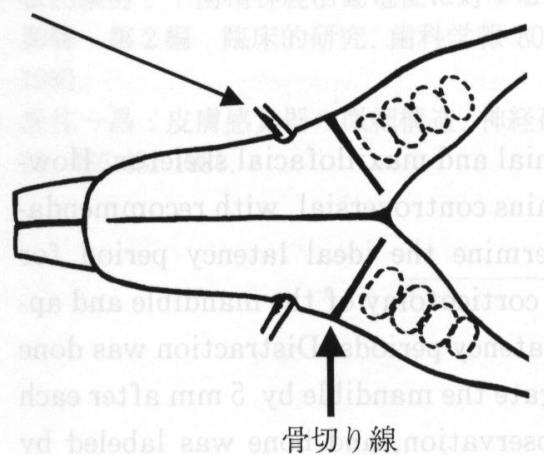

図 1 ウサギ下顎骨骨切りの図

(上 ; 煩側面, 下; 下顎骨下縁)

オトガイ孔と第1自歯の間で皮質骨骨切りを行った.

舌側, 歯槽部皮質骨は完全に骨切りせず, 徒手にて骨折させ た.

を置くことは一般的で, 36時間から15日まで種々の報告が ある ${ }^{7,8)}$. 長管骨とは形態や発生を異にする顔面骨の延長 でも, 臨床的に待機期間は $0 \sim 14$ 日とさまざまであり，統 一の見解はない.

一方, 待機期間について検討した基礎的研究は少なく, 待機期間の相違による延長骨の強度の差はないとする報 告9) と, 待機期間の相違が骨形成量に影響を及ぼすとする 報告10) がある. また,これらの研究は力学的, X 線学的評 価に主眼を置いたもので, 組織学的な評価をした報告はな い.さらにこれらの研究は延長後に一定の日を経過したも ので評価しており初期の骨の形成過程に言及した報告は見 当たらない.

そこで本研究では, 待機期間の必要性, またその最適な 期間を見出すために, ウサギ下顎骨において待機期間の違 いが初期の骨形成に及ぼす影響について組織学的に検討し た.

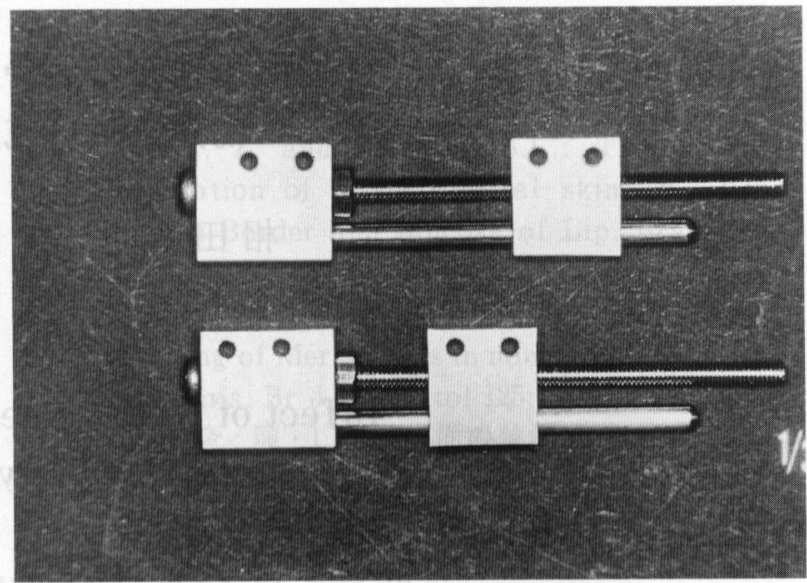

写真 1 自家製創外型延長装置

\section{実験材料と方法}

\section{1. 実験材料}

実験動物には生後 4～6か月, 体重3000g～3500g のウサ ギ (日本白色種), 雄 16 匹を使用した。購入後 1 週間, 室温 24 ${ }^{\circ} \mathrm{C}$, 湿度 $50 \%$ に調節された九州歯科大学動物実験施設飼育 室で固形飼料 $(\mathrm{CR}-3$, 日本クレア社製) と水道水にて飼 育を行い, 全身的に異常がなく健康であることを確認した うえで実験に供した.

なお, 今回のすべての動物実験は九州歯科大学動物倫理 委員会の承認を受け,「九州歯科大学における動物実験に 関する指針」に従って行った.

\section{2 . 実験方法}

ウサギを塩酸ケタミン（ケタラール ${ }^{\circledR}$, アストラ） $60 \mathrm{mg} / \mathrm{kg}$ 筋注と 10 倍希釈ペントバルビタールナトリウム (ネンブタール®,アボット・ラボラトリーズ） $0.35 \mathrm{mg} / \mathrm{kg}$ 緩徐静注による全身麻酔を施した後, 局所の鎮痛, 出血防

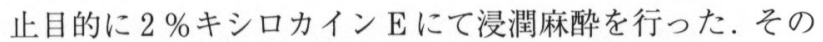
後, 顎下部正中切開により両側の下顎骨下縁を露出させ, 下顎骨体部の骨膜を剥離した. 皮質骨骨切りは, オトガイ 孔と第一兒歯の間で, ダイヤモンドバーを用いて行い, 同 部を若木骨折させた (図 1 ). 骨切り部位から対称的に径 $2.0 \mathrm{~mm}$ キルシュナーワイヤーを 2 本ずつ計 4 本経皮的に 貫通させた. その後, キルシュナーワイヤーとステンレス 製の自家製創外型延長装置 (写真 1 ) をワイヤー結禁線と 即時重合レジンにより固定した (写真 2 ). 骨膜は合成吸収 性綘合系 $\left(4-0\right.$ バイクリル ${ }^{\circledR}$ エチコン社製) により定位 縫合を行い, 皮膚は非吸収性縫合糸 $(4-0$ ナイロン)に より縫合閉鎖した.ウサギの創傷治癒の速度を考慮し，延 長を開始するまでの待機期間を臨床において行われている 


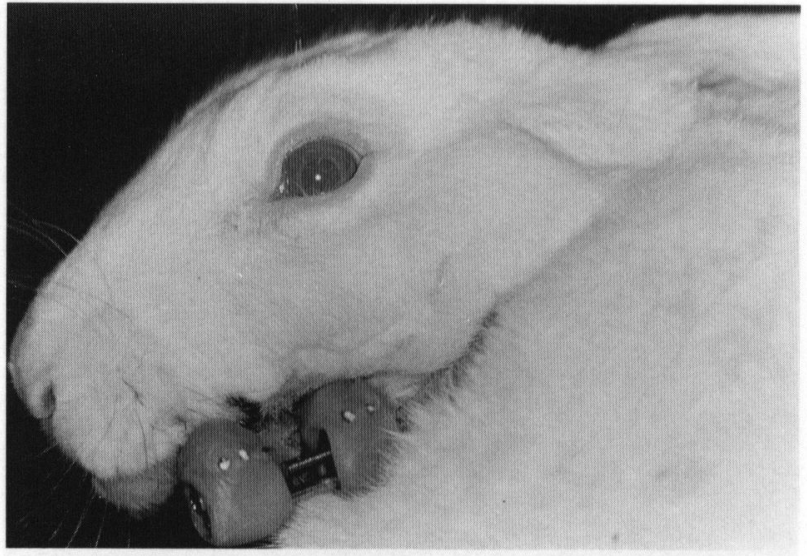

写真 2 延長装置装着写真

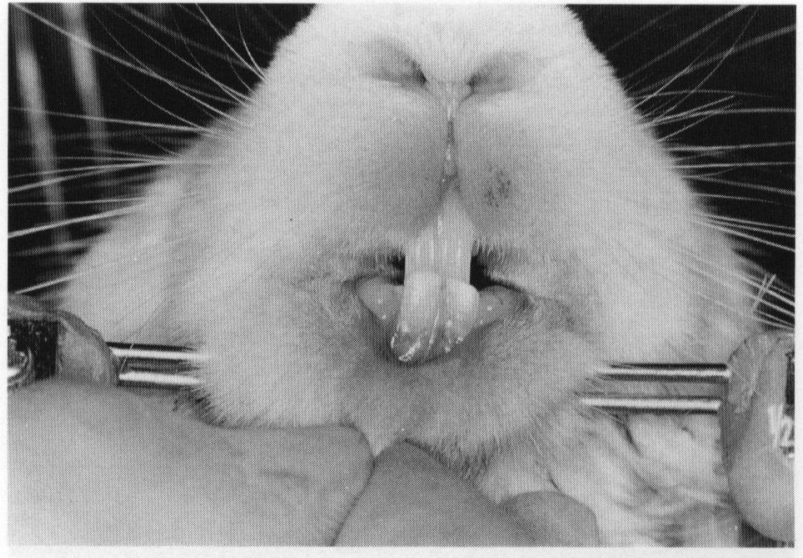

写真 3 延長直後の咬合状態 著明な反対咬合を示している

表 1 実験スケジュール

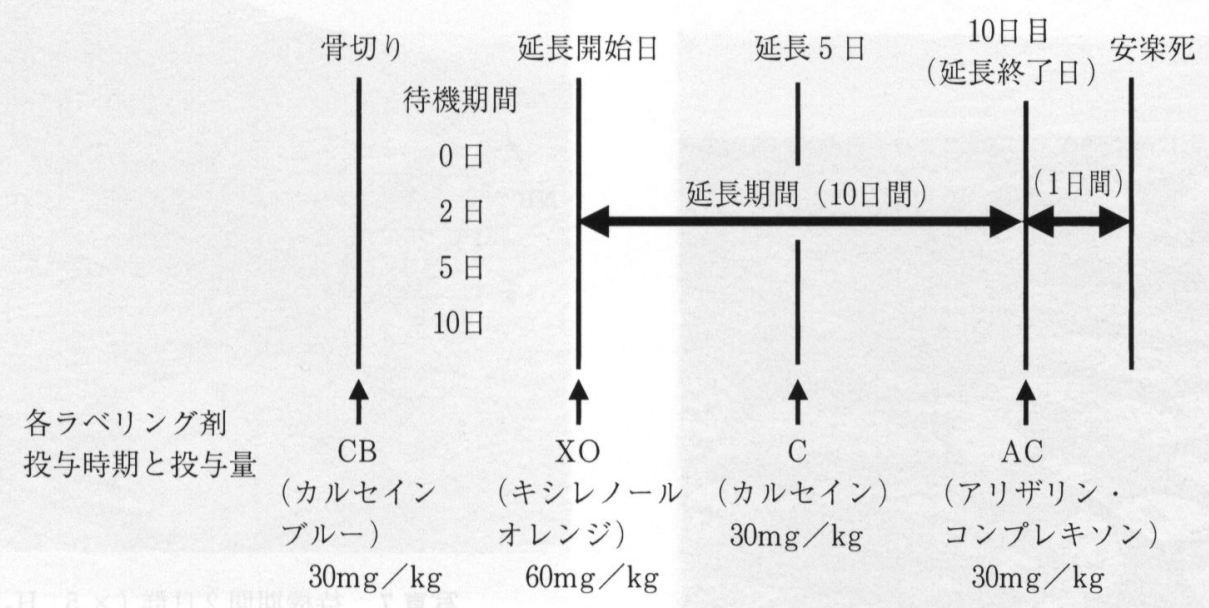

0 日，3 日， 7 日，14日に相当する時期である 0 日， 2 日， 5 日, 10 日 $^{11)}$ とし, 各群 4 匹のウサギを用いた. 各群で待機 期間の後, $0.5 \mathrm{~mm} /$ 日 $(0.25 \mathrm{~mm} / 12 \mathrm{~h})$ の割り合いで延長 を開始し, 10 日間, 計 $5 \mathrm{~mm}$ の延長を行った（写真 3 ). 術 中, 術後に感染予防のためのセフェム系抗菌薬（セファメ ジン®，フジサワ）を筋注にて投与した.また骨の石灰化の 動態をとらえるため, 骨の多色ラベリングを行なった. ラ ベリング剂としてカルセインブルー $(30 \mathrm{mg} / \mathrm{kg})$, キシレ ノールオレンジ $(60 \mathrm{mg} / \mathrm{kg})$, カルセイン $(30 \mathrm{mg} / \mathrm{kg})$, アリザリンコンプレキソン $(30 \mathrm{mg} / \mathrm{kg})$ をそれぞれ, 術直 後, 延長開始時, 延長 5 日目, 延長終了日に皮下注した（表 1 ).

\section{3. 観察方法}

延長終了翌日に両総頸動脈を用いて $10 \%$ ホルマリン液に て潅流固定を行った. 潅流固定後, ウサギの下顎骨を摘出
し10\%中性ホルマリン液にて固定した. 右側下顎骨は $4 \%$ ギ酸にて脱灰し，通法のごとくパラフィン包埋後， $4 \mu \mathrm{m}$ の連続切片標本作製を行い,ヘマトキシリン・エオジン染 色 (H-E 染色) による病理組織学的観察を行った. 左側下 顎骨は非脱灰標本としてアセトンにて脱水後，ポリエステ ル系樹脂（リゴラック）に包埋し, 硬組織薄片切断機 (ゼーゲミクロトーム, ライツ社製) にて約 $100 \mu \mathrm{m}$ の薄切 標本を作成した. 薄切標本はニコン EFD - 2 落射蛍光顕微 鏡を用いてラベリング像を観察した。

\section{実 験 結 果}

\section{1. 病理組織学的所見 (H-E 染色)}

1 ) 待機期間 0 日群

延長中央部は膠原線維と線維芽細胞様の紡錐型細胞から なる線維組織によりほほ満たされ，その配列は延長方向に 


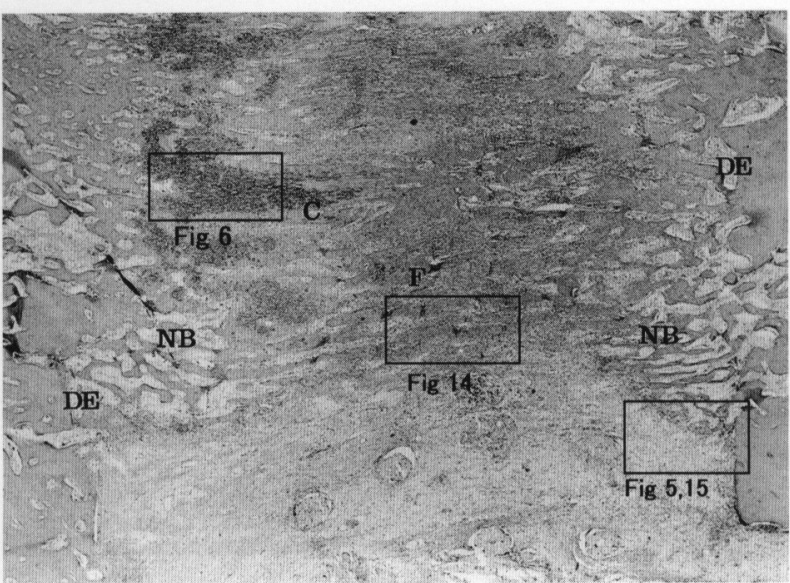

写真 4 待機期間 0 日群 $(\times 5, \mathrm{H}-\mathrm{E}$ 染色 $)$

延長中央部は, 膠原線維と線維芽細胞様の紡鍾型細胞 からなる線維組織 $(\mathrm{F})$ によりほぼ満たされていた。

延長断端部 (DE), 新生骨梁 (NB), 軟骨形成巣 (C)

Fig 5 (写真 5 ), Fig 6 (写真 6), Fig14 (写真 14), Fig15 (写真15)

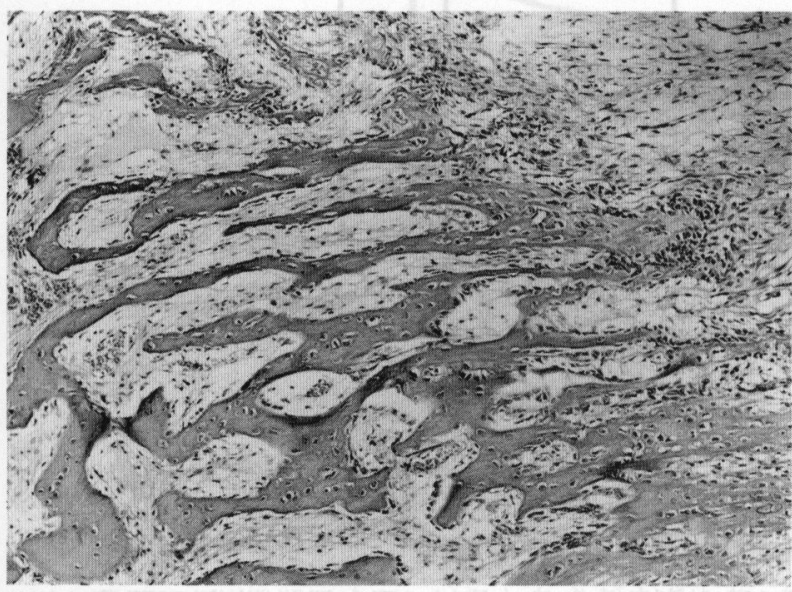

写真 5 待機期間 0 日群 $(\times 10, \mathrm{H}-\mathrm{E}$ 染色 $)$ 延長断端部には延長方向に沿って細く幼弱な新生骨梁 を認めた。

\section{沿って認められた（写真 4$)$.}

延長断端部には延長方向に沿って細く幼弱な新生骨梁を 認めた (写真 5 ). 新生骨梁は $1 \sim 2$ 層の紡錐形ないし立方 形の骨芽細胞によりその周囲を取り囲まれていた。骨梁間 には線維性結合組織と拡張した新生血管が認められた。

また，延長断端部には軟骨形成巣が島状に配列しており (写真 6 ), その周囲は幼弱な骨梁により取り囲まれていた. 延長部の骨膜側においては, 骨膜付近の新生骨梁の形成は 認められなかった。

2 ) 待機期間 2 日群

延長中央部に線維組織が認められたが,この線維組織は

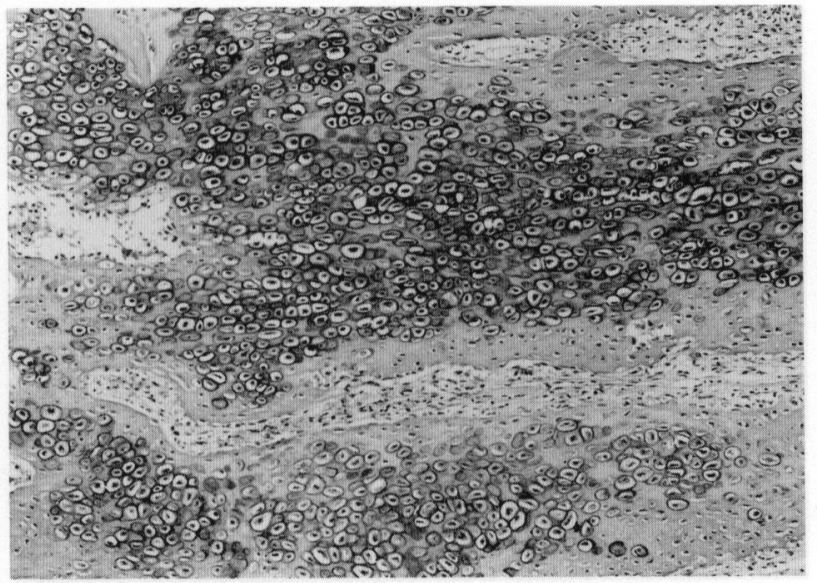

写真 6 待機期間 0 日群 $(\times 25, \mathrm{H}-\mathrm{E}$ 染色 $)$ 延長断端部には，軟骨形成巣が島状に配列しており， その周囲は幼弱な骨梁により取り囲まれていた。

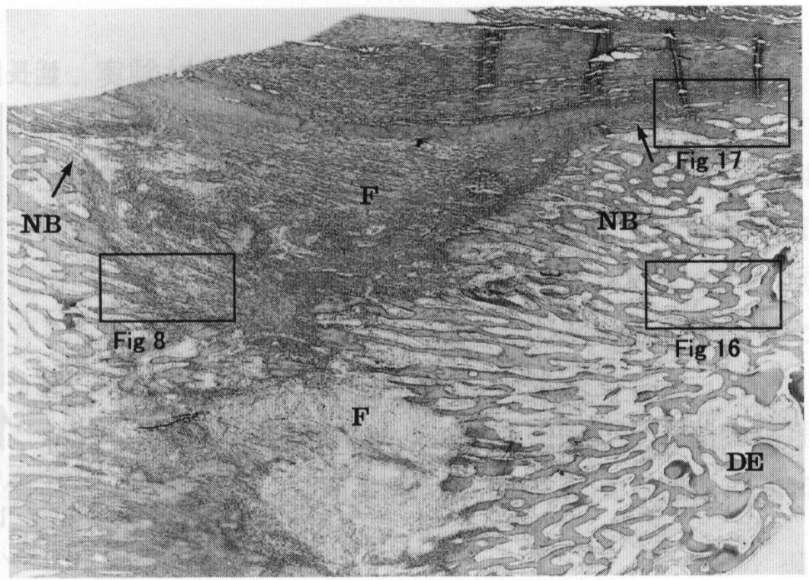

写真 7 待機期間 2 日群 $(\times 5, \mathrm{H}-\mathrm{E}$ 染色 $)$ 延長中央部に線維組織（F）が認められたが, 待機期間 0 日群に比べその量は減じていた。骨膜周囲の骨新生像 (矢印) が延長断端部の一部で認められた.

延長断端部 (DE), 新生骨梁 (NB)

Fig 8 (写真 8 ), Fig16 (写真16), Fig17 (写真17)

待機期間 0 日群に比べてその量は減じていた (写真 7 )。こ の線維組織の中枢側と末梢側に未熟な細い新生骨梁が認め られた (写真 8 ). 膠原線維と新生骨梁は延長長軸方向に 沿って伸長していた。

延長断端部骨梁は待機期間 0 日群と比較し幅が広く, 骨 梁内部には骨細胞を封入している部分も認められた。骨梁 周囲には扁平ないし立方形の骨芽細胞が認められた。その 周囲には拡張した新生血管が多数認められた。

軟骨形成巣は断端部周囲に島状に散在していたが，待機 期間 0 日群と比較してその量は少なかった。同部の骨梁周 囲を取り囲む骨芽細胞は待機期間 0 日群よりも増加してい 


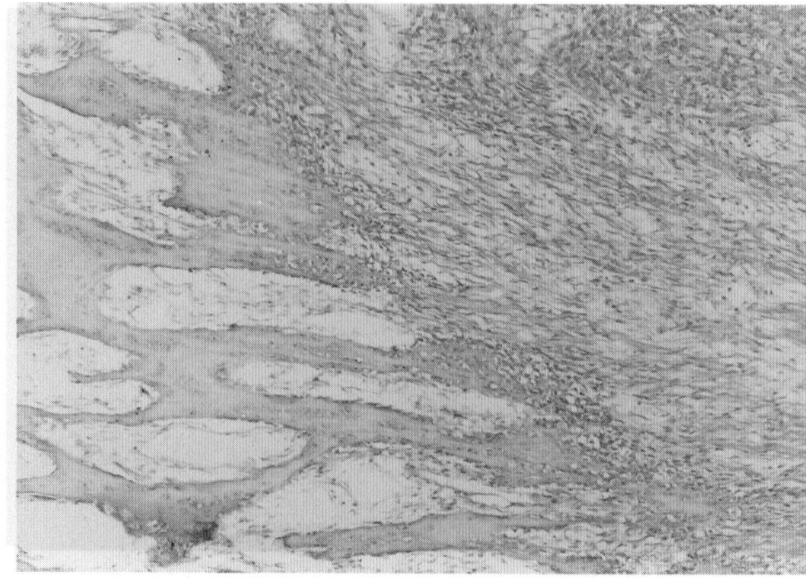

写真 8 待機期間 2 日群 $(\times 25, \mathrm{H}-\mathrm{E}$ 染色 $)$

延長中央部線維組織の中枢側と末梢側に未熟な細い新 生骨梁が認められた.

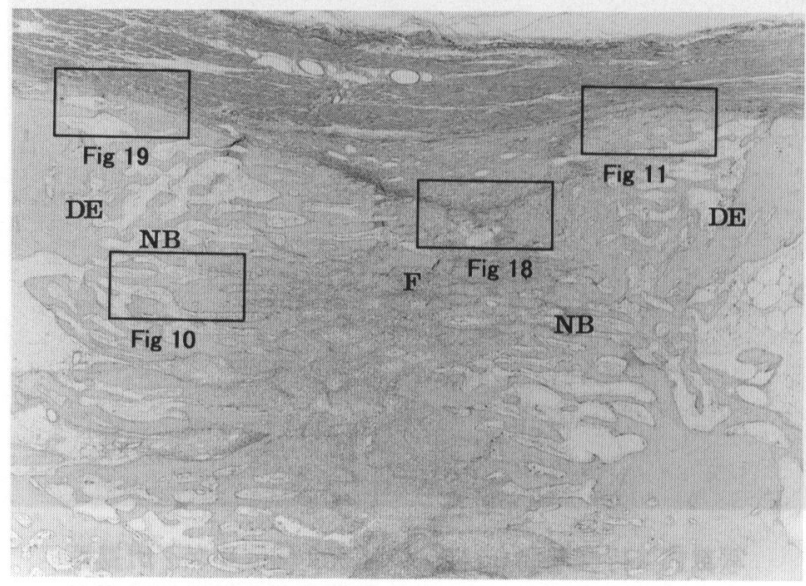

写真 9 待機期間 5 日群 $(\times 5, \mathrm{H}-\mathrm{E}$ 染色 $)$

延長中央部では, 線維芽細胞様の紡錘型細胞と膠原線 維からなる線維組織 $(\mathrm{F})$ が認められ, その中枢側と末梢 側に未熟で細い新生骨梁 (NB) が認められた。

延長断端部 (DE)

Fig10 (写真10), Fig11（写真11）, Fig18（写真18）, Fig19 (写真19)

た. 骨膜側では骨膜周囲の骨新生所見が延長断端部の一部 でのみ認められた。

\section{3 ) 待機期間 5 日群}

延長中央部では線維芽細胞様の紡錐形細胞と膠原線維か らなる線維組織が認められ,これを挟むように未熟で細い 新生骨梁が認められた. 線維組織の占める割合は待機期間 2 日群よりさらに小さく, 未熟な骨梁が占める割合が増し ていた (写真 9 ).

延長断端部骨梁の幅は待機期間 2 日群よりもその幅を増 し, 骨梁内部への骨細胞の封入はさらに進行していた. 新

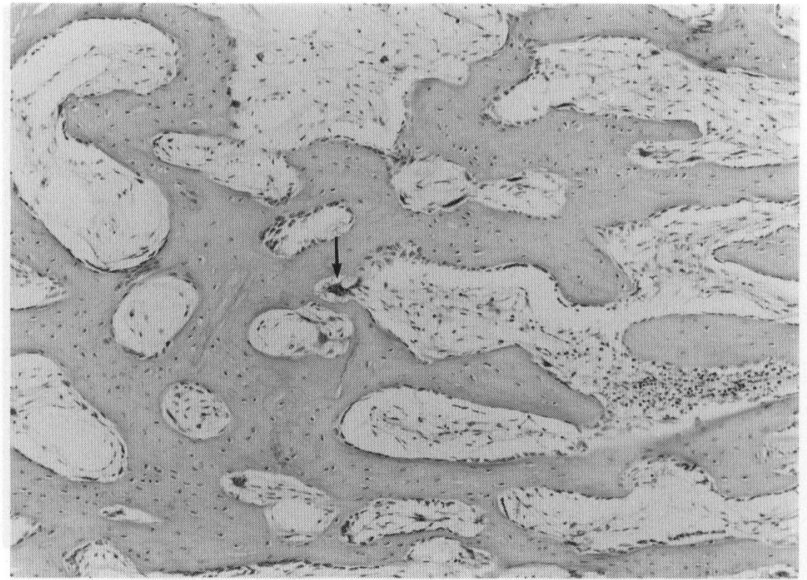

写真10 待機期間 5 日群 $(\times 25, \mathrm{H}-\mathrm{E}$ 染色 $)$

延長断端部新生骨梁. 骨梁の幅は待機期間 2 日群より 広く骨梁同士の架橋による網状構造を認めた。骨梁周囲 に破骨細胞（矢印）を認めた.

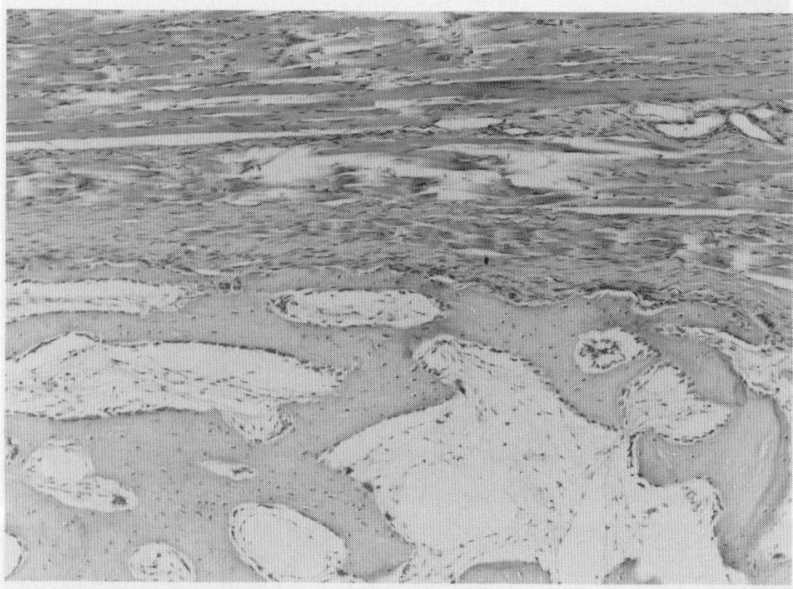

写真11 待機期間 5 日群 $(\times 25, \mathrm{H}-\mathrm{E}$ 染色 $)$

延長部に隣接する断端部付近の骨膜から連続する骨新 生像を認めた。
生骨梁周囲全体を取り囲むように扁平ないし立方形の骨芽 細胞が規則正しく配列し, その周囲には新生血管が多数散 在していた. 延長断端部骨梁の一部には破骨細胞も認めら れた (写真10). 新生骨梁は断端部に近づくほど骨梁同士の 連絡による網状構造を呈していた. 断端部からやや中央部 よりの骨梁では骨梁と骨梁を結ぶ骨芽細胞の集積部分も認 め, 活発な骨新生が示唆された. また, 新生血管の血管壁は 厚さを増し, 動脈様構造を呈するものも認められた.

断端部における軟骨形成巣の量は待機期間 2 日群と同程 度で, その量は少なかった. 周囲の骨芽細胞も待機期間 0 


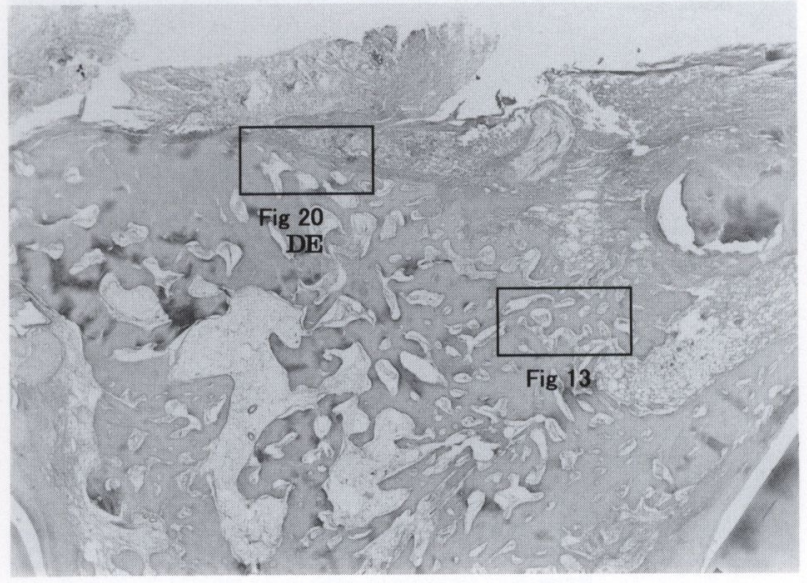

写真 12 待機期間 10 日群 $(\times 5, \mathrm{H}-\mathrm{E}$ 染色 $)$ 延長部に認められる線維組織は他の群に比較し,きわ めて少なかった、軟骨形成巣はほとんど認められなかっ た.

延長断端部 (DE)

Fig13 (写真13), Fig20 (写真20)

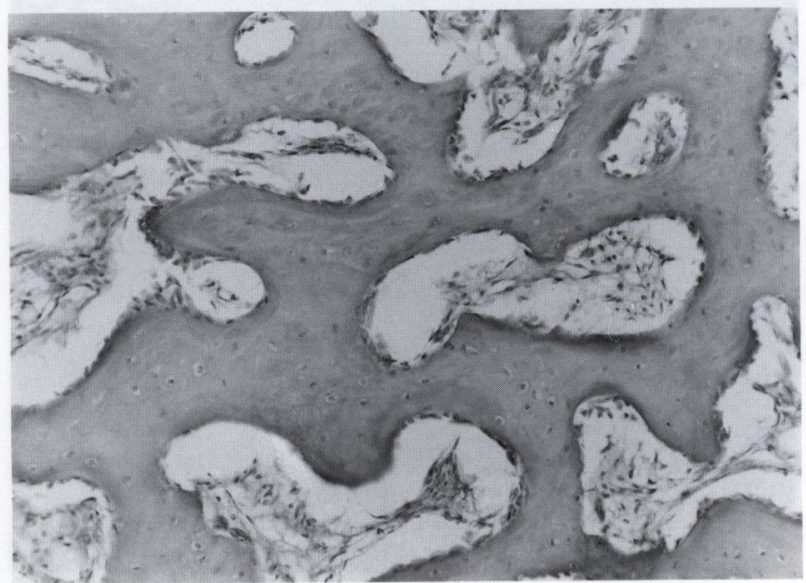

写真13 待機期間 10 日群 $(\times 50, \mathrm{H}-\mathrm{E}$ 染色 $)$

延長断端部付近の新生骨梁は骨芽細胞, 破骨細胞の出 現による骨改造の初期の様相を呈していた.

日群，2 日群よりも多く認められた。延長部に隣接する断 端部付近の骨膜から連続する骨新生像を認めた（写真11）. この所見は待機期間 2 日群と比較し, 延長断端部だけでな く中央部にまで及んでいた. 骨膜と骨梁間には多数の骨芽 細胞が認められた。

4 ) 待機期間10日群

延長部に認められる線維組織は他の群に比較してきわめ て少なく（写真12）, 延長部は内部に骨細胞を封入する非常 に幅広く成熟した新生骨梁により満たされていた。断端部 では延長部との境界が不明瞭となり, 延長中央部では網状

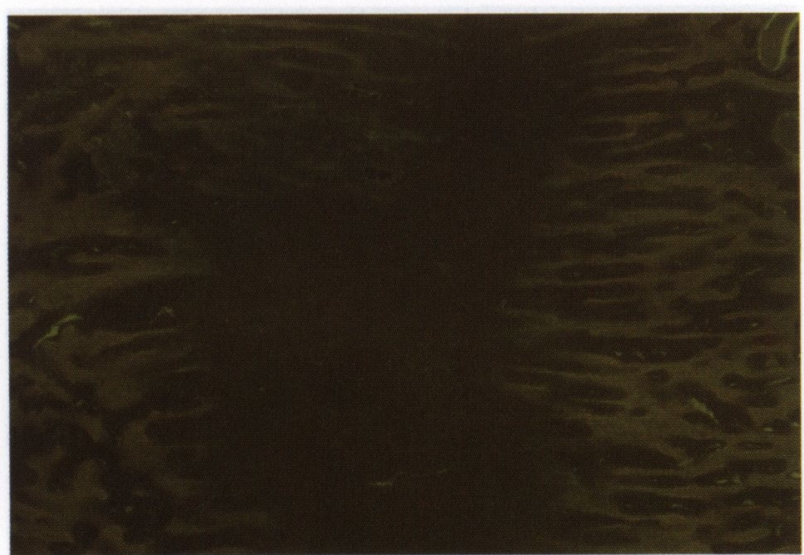

写真14 待機期間 0 日群 $(\times 6.25$, ラベリング所見 $)$ 延長中央部は骨梁の連絡がほとんどなく,ラベリング されていない部分が広い範囲で認められた。

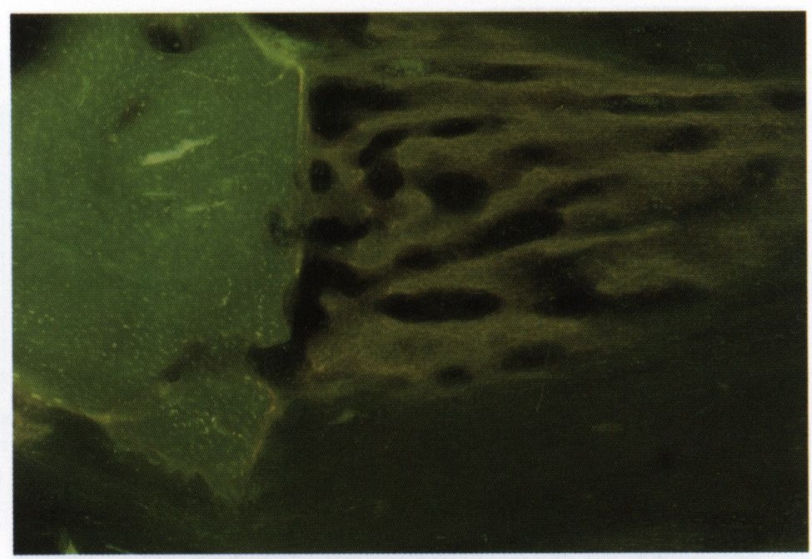

写真15 待機期間 0 日群 $(\times 12.5$,ラベリング所見 $)$ 骨膜側周囲にはラベリングは認められなかった。

構造を呈し, 母床骨の骨䯣と類似した所見を呈していた́。 断端部付近の新生骨梁は骨芽細胞, 破骨細胞の出現による 骨改造の初期の様相を呈していた (写真13). 骨梁周囲には 他の群に比較し,より成熟した新生血管を多数認めた.

軟骨形成巣は待機期間 2 日群，5 日群と同程度であった。 同部の骨梁周囲は一層の骨芽細胞の配列を認めた.また, 骨膜から延長部へ伸長した新生骨梁が認められ，骨膜から の骨新生が示唆された.

\section{2.ラベリング所見}

1 ) 待機期間 0 日群

延長中央部は, 骨梁の連絡がほとんどなく, ラベリング されていない部分が広い範囲で認められた (写真14). 延長 断端部では, 中央部へ伸びる細い骨梁の周囲を一層取り囲 


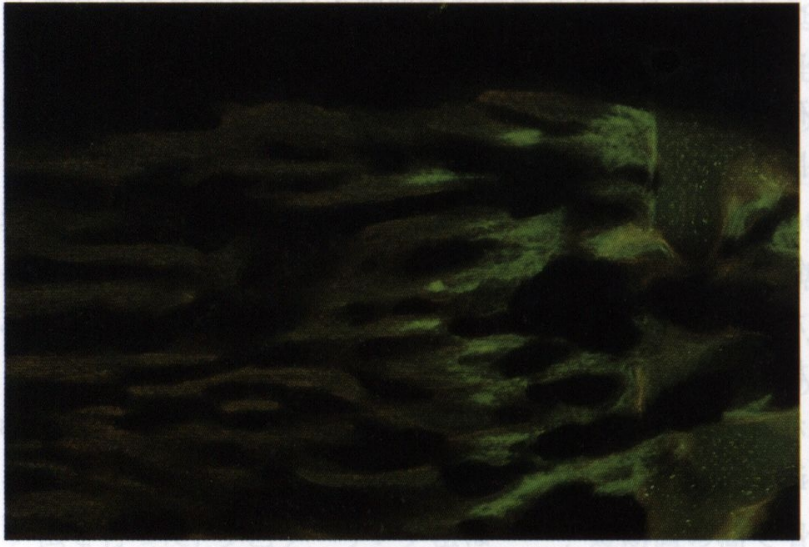

写真16 待機期間 2 日群 $(\times 12.5$, ラベリング所見 $)$

カルセインのラベリングは, 延長断端部付近の骨梁内 に認められた。

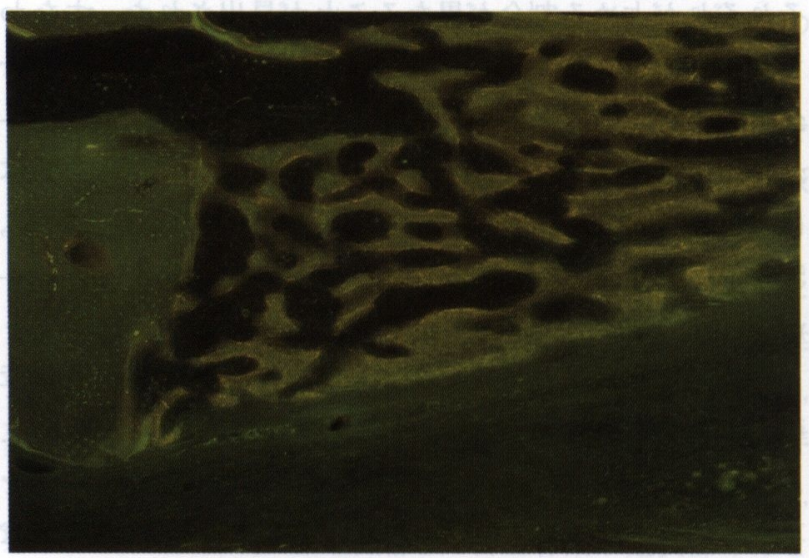

写真17 待機期間 2 日群 $(\times 12.5$, ラベリング所見 $)$ 骨膜と延長部の境界付近にラベリングは認められなかっ た.

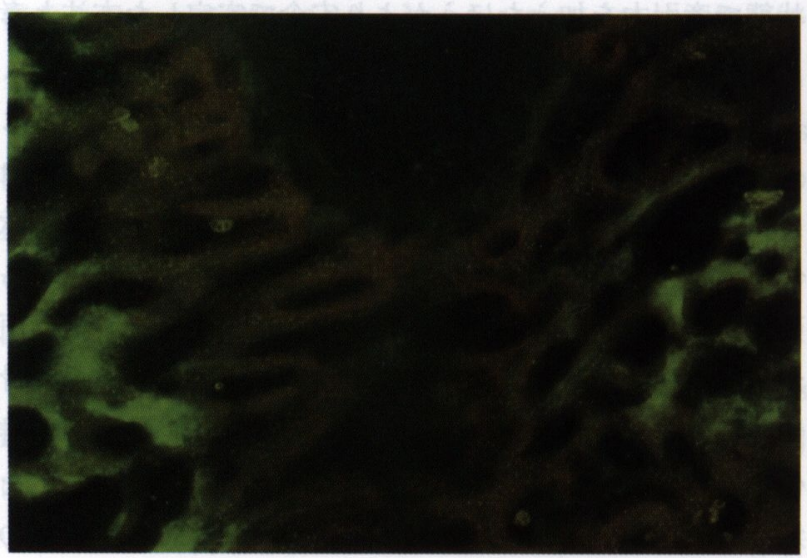

写真18 待機期間 5 日群 $(\times 12.5$, ラベリング所見 $)$ キシレノールオレンジラベリングは延長断端部から中 央部へかけて認められた。

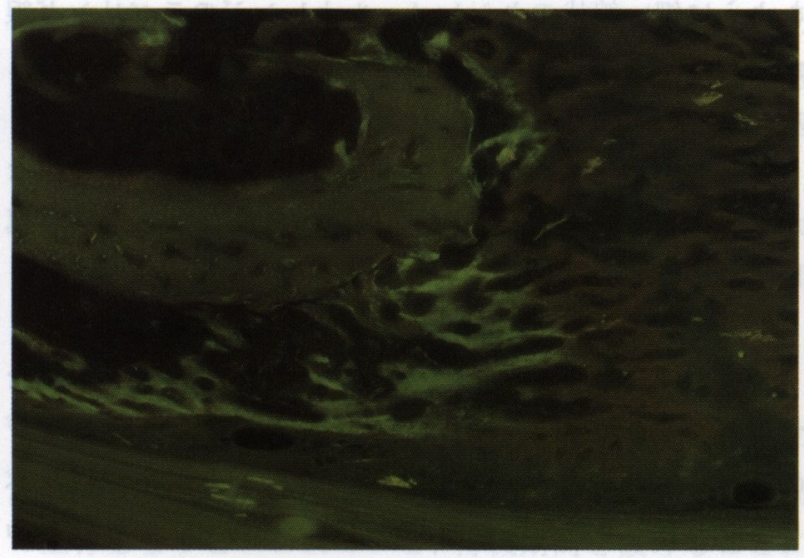

写真19 待機期間 5 日群 $(\times 6.25$, ラベリング所見 $)$ 延長断端部付近の骨膜から伸長した骨梁にも同様のカ ルセインによるラベリングを認めた.
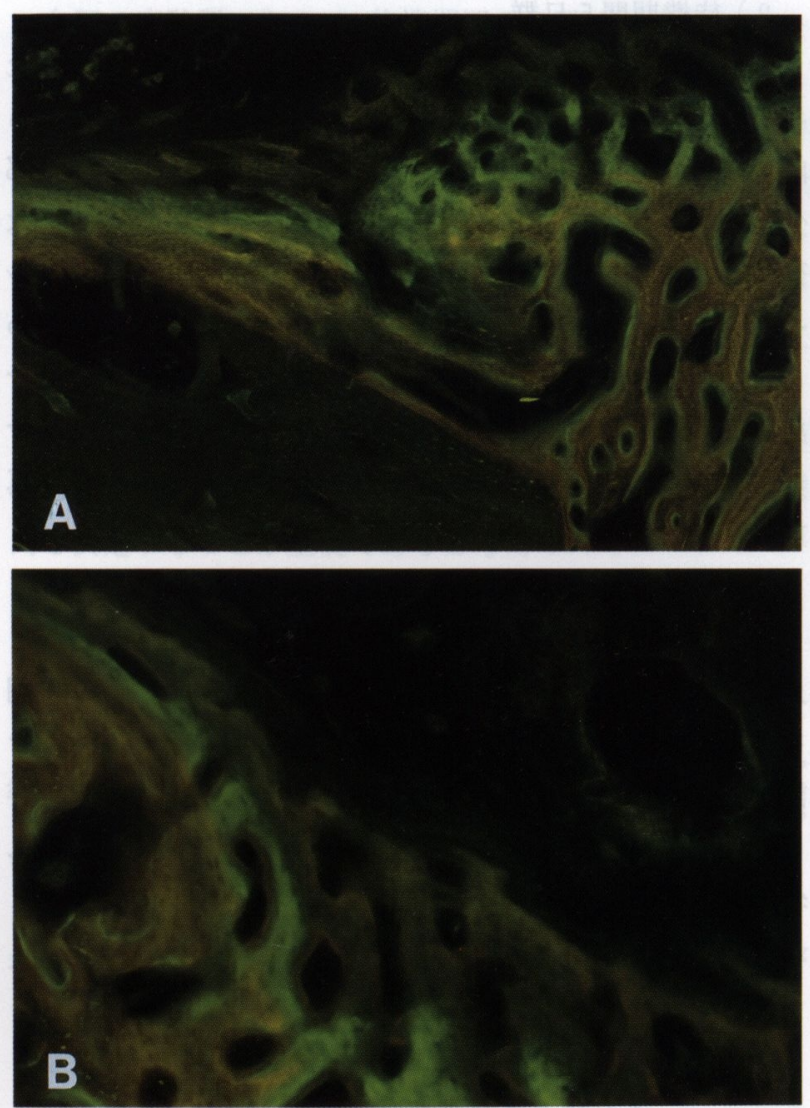

写真 20A, B 待機期間 10 日群

$(\mathrm{A} \times 12.5, \mathrm{~B} \times 31.3$, ラベリング所見 $)$

骨膜周囲の新生骨梁内部にカルセインによるラベリン グが認められた。 
むように細い線状のキシレノールオレンジのラベリング線 が認められたが, ラベリング線は延長中央部へ向かうにし たがって不明瞭となっていた。

カルセインのラベリングは延長部において認められな かった. 骨膜周囲のラベリングは認められなかった（写真 15).

2 ) 待機期間 2 日群

待機期間 0 日群と同様に, 延長断端部から伸びる幼弱な 骨梁の周囲を一層取り囲むように, キシレノールオレンジ のラベリングが認められた. キシレノールオレンジにラベ リングされた骨梁は待機期間 0 日群と比較し，より延長中 央部まで進展を認め, そのラベリングの幅も増加していた。

カルセインのラベリングは待機期間 0 日群に比較し若干 の増加を示し, 断端部付近の新生骨梁内部にのみ認められ た (写真16).

骨膜周囲にラベリングは認められなかった（写真17）.

3 ) 待機期間 5 日群

待機期間 0 日群, 2 日群では骨梁周囲にのみ認められた キシレノールオレンジによるラベリングは, 骨梁周囲から 内部まで存在し, 幅広いラベリング線として認められる部 分と細い線状の部分とが混在していた。 そのラベリングは 延長断端部から中央部へかけて認められた (写真18). カル セインのラベリングは延長断端部から中央部付近まで認め られ, 待機期間 0 日群, 2 日群と比較して, 幅の広い新生骨 梁内部に認められた. 延長断端付近の骨膜から伸長した骨 梁にも同様のカルセインによるラベリングを認めた（写真 19).

4 ) 待機期間10日群

キシレノールオレンジのラベリングは待機期間 5 日群と 比較し，より骨梁中心部まで全体的に認められ，その周囲 を取り囲むようにカルセインの幅広い線状のラベリングを 認めた.カルセインにラベリングされている部分は他の群 と比較して最も多く延長部のいたるところで認められた。 骨膜から伸長している骨梁内部にカルセインによるラベリ ングが認められた（写真20A，B）。

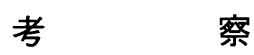

仮骨延長法における待機期間の必要性について Tavakoli ら ${ }^{9)}$ は, 待機期間を 0 日，4 日， 7 日としたヒッ ジ下顎骨延長の研究で, 骨密度測定, 力学的強度の測定を 行っている.それによるとそれぞれの群間に有意差はなく， 待機期間は必ずしも必要なものではないと報告している. 一方, White ら ${ }^{10)}$ はウサギ脛骨延長の研究で, 待機期間を 0 日群と 7 日群としコンタクトマイクロラジオグラフィー, マイクロアンギオグラムを用いた比較検討を行っている.
その結果, 延長後 6 週で待機期間 7 日群が 0 日群と比較し て新生骨形成量が多いと報告している。このように実験的 研究においても待機期間の必要性とそれがどれくらいの期 間必要なのかは見解の一致をみない.

仮骨延長法に㧍ける骨形成過程の組織像についてその報 告は多い. Mikhail ら ${ }^{12)}$ は, 緩徐にかつ持続的に㐮引され た骨片間隙の中央部は延長長軸方向に配列した線維芽細胞 様の紡錐型細胞と膠原線維に富む幼弱な結合組織で形成さ れる中間層（fibrous inter zone）を認める。この fibrous inter zone を挟む形で, 骨芽細胞や延長長軸方向に配列し た未熟な骨梁 (mineralization zone) が㴓められるとして いる.さらに延長断端部には，これらを挟む形で新生骨梁 が網状構造を呈し，破骨細胞も認められ，骨の改造の所見 が認められる (remodeling zone) と述べている.

本実験結果から，待機期間が異なれば，延長部において fibrous inter zone, mineralization zone, remodeling zone, それぞれが占める割合が異なることが見出された.すなわ ち, 待機期間 0 日群では, 線維組織に満ちた fibrous inter zone でほほ延長部は占められ，延長断端部に mineralization zone が認められた. 待機期間10日群では, 延長部は ほほ remodeling zoneで占められていた. 待機期間 2 日群, 5 日群では, fibrous inter zone, mineralization zone, remodeling zoneがほほ規則正しく配列していた。

今回の実験は延長直後に観察を行っており，延長中に毫 引力が加えられる状態での組織像を観察しているといえ る. 仮骨延長法は本来, 未熟な骨梁に牽引力を加えて骨を 再生する方法であるが, 待機期間 0 日群では延長部はほほ 線維組織に満たされており,この牽引力は線維組織に加え られると考えられた。一方待機期間 2 日群，5 日群では，延 長部に細く未熟な骨梁が多く認められた。線維組織が残存 する可能性や，感染の危険性を考えると，延長部が線維組 織で満たされた状態で延長を行うより，未熟な骨梁が多い 状態で牽引力を加えたほうがより安全で安定した方法と考 えられた。

また待機期間 0 日群では, 延長部に多量の線維組織とと もに他の群と比較し多量の軟骨形成巣を認めた. Bassett ら ${ }^{13)}$ は, 骨折の治癒の際, 組織の酸素分圧が低いときに軟 骨が出現しやすいと報告している.仮骨延長法においても 延長部に軟骨形成巣が多いということは, 同部の酸素分圧 が低い状態であったことが予想された。骨切り直後は，骨 切り部に血腫が形成される. Brighton ら ${ }^{14)}$ はウサギの腓 骨において酸素濃度の計測を行ない, 血腫内が最低の值を 示し，骨幹部では最高の值を示したと報告している。この ため血腫が肉芽組織に置換される以前に延長が開始される 待機期間 0 日群では, 多量の軟骨形成巣を認めたと推察さ れた。 
長管骨は骨折の治癒時には軟骨内骨化を示すが, 仮骨延 長時の骨化は中央部では膜性骨化, 骨膜下では軟骨内骨化 であると報告されている ${ }^{1,15 \sim 19)}$ ，一方下顎骨では，骨折の 治癒時には膜性骨化を示すが, 仮骨延長時における骨再生 機序は, 膜性骨化あるいは軟骨内骨化，また双方の骨化が 起こるとの意見があり ${ }^{20,21)}$,一定の見解はない．また出現 した軟骨組織が軟骨内骨化によって骨へ置換されるのか, あるいはそのまま軟骨組織として残存するのかは不明であ り, 今後の研究の待たれるところである.

今回, 骨の石灰化の動態をとらえるため, 多色ラベリン グ法を行った. 多色ラベリング法は22, 23)，短期間の間で骨 が旺盛に成長してゆく時期に骨の石灰化の状態を検索する 方法である. 延長開始時に投与したキシレノールオレンジ は骨梁の周囲にラベリングを認め, 延長 5 日目に投与した カルセインは, おもに待機期間 5 日群では骨梁内部に認め られた, 待機期間10日群では, 骨梁内部はキシレノールオ レンジのラベリングに満たされ，その周囲をカルセインの ラベリングが覆っていた。

このことから，まず未熟な新生骨梁周囲が石灰化し，そ の後内部が石灰化すること,その後さらに骨梁周囲の石灰 化が起こると推察された.

前述したように仮骨延長法は未熟な骨梁に牽引力を加え て骨の再生を図る方法であり, 待機期間10日群のように延 長部の新生骨梁の石灰化が進行しているような状態では, 延長するには適さないことが考えられた. 待機期間 10 日群 では, 病理組織学的所見で線維組織はほとんど認められず, 未熟な新生骨梁は少なく成熟した新生骨梁が延長部のほと んどを占めていた. 実際に他の群に比べ, 延長時の抵抗が 強かった。

White ら ${ }^{10)}$ はウサギ脛骨における延長時の抵抗は, 待機

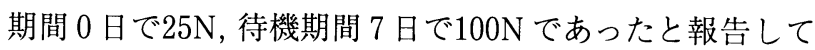
いる.またChin らは24)，待機期間が長すぎると早期に骨性 癒着を起こす可能性があるため， 0 ～ 5 日で延長を開始す るとしている.一方で, De Bastiani ${ }^{25)}$ は待機期間を14日と し，骨切り部に仮骨を形成させた後に延長を行う Callotatis 法を報告している。しかし，四肢骨よりも周囲組織からの 血流が豊富である顔面骨においては, 待機期間を長く置き すぎることは延長部に早期の骨硬化を引き起こし，延長を 困難とすることが示唆された。

待機期間 2 日群と待機期間 5 日群を比較すると fibrous inter zone, mineralization zone, remodeling zone の配列 は，両群ともにほぼ規則正しく，未熟な新生骨梁に富んで いた. しかし待機期間 5 日群では著明に，骨膜からの骨新 生像を示唆する所見や骨膜周囲に骨芽細胞の出現を認めた が，2 日群ではこのような所見は一部でしか認められな かった。
仮骨延長法において, 骨膜の果たす役割は大きいといわ れている. 仮骨延長法は腫瘍切除後などの骨膜がない状態 での延長も可能であるが，その場合骨形成は劣るといわれ ている. Kojimoto ら ${ }^{19)}$ は幼若ウサギで骨膜を除去した群， 骨髄を除去した群を作製し，骨膜と骨髄の役割についての 実験的研究を行っている.それによると，X線学的および 組織学的に骨膜除去群では, 著明に仮骨形成が障害され， 骨膜の温存の重要性を述べている.

一般に, 骨膜の内層には，いわゆる骨形成細胞 (Osteogenitor cell）が豊富でこれが骨芽細胞へと分化し骨形成 の主体をなすといわれている，待機期間を設けることに よって骨膜を中心とした周囲軟組織を治瘉させることは， より速やかに骨形成を導く要因の1つと考えられる.今回 の実験では, 骨膜に切開, 剥離という侵襲を加えており, 待 機期間が長ければ骨膜の治癒は良好で, 同部からの骨新生 や, 周囲の骨芽細胞の出現も著明となったと考えられた.

今回の実験群のなかで, 待機期間 5 日群は, fibrous inter zone, mineralization zone, remodeling zone が規則正し く配列し, 未熟な新生骨梁に富んでいた. 待機期間 2 日群 に比べて骨膜の治瘉の状態も良好であり,最も適した待機 期間であると考えられた. ウサギの創傷治瘉速度を考える と，5日はヒトに置き換えると 7 日に相当するとされてい る. 臨床においても 7 日間の待機期間を置く報告は多く， これを裏付ける結果となった。

しかし年齢, 手術法, 固定法の安定性など骨形成に影響 する因子は数多く, 今回の結果にこれらを加味して待機期 間を決定することが重要であると考えられた。

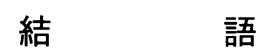

ウサギ下顎骨を用いて仮骨延長法を行い, 待機期間が, 初期の骨形成に与える影響について組織学的検討を行い, 以下のような結果を得た。

1. 待機期間が異なれば, 延長部において fibrous inter zone, mineralization zone, remodeling zone，それぞれが 占める割合が異なっていた。

2 . 待機期間 0 日群では, 延長部に多量の線維組織とと もに他の群と比較し多量の軟骨形成巣を認めた。

3 . 待機期間10日群では, 線維組織はほとんど認められ ず，未熟な新生骨梁は少なく，成熟した新生骨梁が延長部 のほとんどを占めていた．

4. 待機期間 5 日群, 待機期間 10 日群では著明に, 骨膜か らの骨新生を示唆する所見や骨膜周囲に骨芽細胞の出現を 認めた。

5 . 待機期間 5 日群は, fibrous inter zone, mineralization zone, remodeling zone が規則正しく配列し，未熟 
な新生骨梁も豊富であった. 待機期間 2 日群に比べて骨膜 からの骨新生も著明であり, 最も適した待機期間であると 考えられた。

\section{引用 文 献}

1) Ilizarov, G.A.: The tension-stress effect on the genesis and growth of tissues: part I ; The influence of stability of fixation and soft tissue preservation. Clin Orthop 238: 249-281 1989.

2) Ilizarov, G.A.: The tension-stress effect on the genesis and growth of tissues: part II ; The influence of the rate and frequency of distraction. Clin Orthop 239: 263-285 1989.

3) Snyder, C.C., Levine, G.A., et al.: Mandibular lengthening by gradual distraction; Preliminary report. Plast Reconstr Surg 51: 506-508 1973.

4) McCarthy, J.G., Schreiber, J., et al.: Lengthening of the human mandible by gradual distraction. Plast Reconstr Surg 89: 1 - 81992.

5) Yonehara, Y., Takato, T., et al.: Secondary lengthening of the reconstructed mandible using a gradual distraction technique-two case reports. Br J Plast Surg 51: 356-358 1998.

6) Block, M.S., Chang, A., et al.: Mandibular alveolar ridge augmentation in the dog using distraction osteogenesis. J Oral Maxillofac Surg 54: 309-314 1996.

7) Aldegheri, R., Renzi-Brivio, L., et al.: The callotasis method of limb lengthening. Clin Orthop 241: 137-145 1989

8) De Pablos, J., Villas, C., et al.: Bone lengthening by physeal distraction. An experiment study. Int Orthop 10: 1631986.

9) Tavakoli, K., Walsh, W.R., et al.: The role of latency in mandibular osteodistraction. J Craniomaxillofac Surg 26: 209-219 1999.

10) White, S.H. and Kenwright, J.: THE TIMING OF DISTRACTION OF AN OSTEOTOMY. J Bone Joint Surg Am 72: 356-361 1990.

11）橋本房三 : 抜歯創治癒過程の組織学的, 生化学的研 究. 鶴見歯学 10: 297-317 1984.

12) Mikhail, L.S., Alexander, M.C., et al.: Distraction osteogenesis: Origins and Evolution.
McNamara, J.A. Jr. and Carroll-Ann, T.: Distraction osteogenesis and tissue engineering. 1st Ed, The University of Michigan, Michigan, 1997, p1 -35.

13) Bassett, C.A.L.: Current concepts of bone formation. (Instructional corse lecture) J Bone Joint Surg Am 44: 1217-1244 1962.

14) Brighton, C.T. and Krebs, A.G.: Oxygen tension of healing fractures in the rabbit. J Bone Joint Surg Am 54: 323-332 1972.

15) Alho, A., Bang, G., et al.: Filling of a bone defect during experimental osteotaxis distraction. Acta Orthop Scand 53: 29-34 1982.

16）廣島和夫：脚延長の基礎。日整会誌 63：593-605 1989.

17) Korkala, O., Karaharju, E., et al.: Experimental lengthening of tibial diaphysis: gap healing with or without gradual distraction. Arch Orthop Trauma Surg 107: 172-175 1988.

18) Delloye, C., Delefortrie, G., et al.: Bone regenerate formation in cortical bone during distraction lengthening. An experimental study. Clin Orthop 250: 34-42 1990.

19) Kojimoto, H., Yasui, N., et al.: Bone lengthening in rabbits by callus distraction. The role of periosteum and endosteum. J Bone Joint Surg Br 70: 543-549 1988.

20) Komuro, Y., Takato, T., et al.: The histlogic analysis of distraction osteogenesis of the mandible in rabbits. Plast Reconstr Surg 94: 152-159 1994.

21) Sawaki, Y., Ohkubo, H., et al.: Mandibular leng thening by intraoral distraction using osseointegrated implants. Int J Oral Maxillofac Implants 11: 186-193 1996.

22）福田仁一: 顎骨骨折の治癒へのソルコセリルの影響 に関する実験的研究. 日口外誌 35: 14-25 1989.

23）高橋 学: 石灰化組織の多色ラベリングのためのラ ベリング剂投与方法について. 歯学 67: 53-66 1979.

24) Chin, M. and Toth, B.A.: Distraction osteogenesis in maxillofacial surgery using internal devices: review of five cases. J Oral Maxillofac Surg 54: 45-53 1996.

25) De Bastiani, G., Aledegheri, R., et al.: Limb lengthening by callus distraction (callotasis). J Pediatr Orthop 7 : 129-134 1987. 